\title{
Prediction of capacity of geothermal doublet located in the vicinity of Kalisz using the numerical modeling
}

\author{
Anna Wachowicz-Pyzik ${ }^{1, *}$, Anna Sowiżdża1 ${ }^{1}$, and Leszek Pająk $^{2}$ \\ ${ }^{1}$ AGH University of Science and Technology, Faculty of Geology, Geophysics and Environment \\ Protection, Department of Fossil Fuels, al. A. Mickiewicza 30, 30-059 Kraków, Poland \\ ${ }^{2}$ AGH University of Science and Technology, Faculty of Mining Surveying and Environmental \\ Engineering, Department of Environmental Management and Protection, al. A. Mickiewicza 30, \\ 30-059 Kraków, Poland
}

\begin{abstract}
Attaining the proper values of main production parameters of operating geothermal installation: outflow, temperature, water level in production well and required injection pressure in a well for reinjection may significantly reduce the costs of energy production. Lower production costs compensate high investment expenditures and reduce the energy prices down to an acceptable level, competitive in relation to conventional energy sources. In the research project, we used the TOUGH2 simulator to select configuration of geothermal doublet and to estimate the discharge of potential geothermal installation localized in the vicinity of Kalisz and based upon the existing Zakrzyn IG-1 well. Considering the measurements and other information gained during the drilling operations, the conceptual model was generated. In order to select the optimal configuration of the doublet, which would ensure the maximum yield, the analysis was carried out on the influence of production/injection wells spacing on production parameters. The optimization aimed to determine the minimum spacing which would guarantee that the injection well would not affect the temperature of fluid discharged from the production well within the presumed circulation time.
\end{abstract}

\section{Introduction}

The numerical models commonly applied in solutions of various geological and hydrogeological problems are frequently used also in geothermics [1]. Thanks to graphic visualization, such models are useful in spatial imaging of geological and structural data. However, even more important is the opportunity provided by the models to reconstruct the processes operating within the reservoir during the discharge of fluids and the yield of energy [2-8]. At the initial phase of recognition of reservoir properties, the quantitative analyses may provide key data enabling the designers to reduce investment expenditures. The premeditated configuration of geothermal waters intake by selection of proper localization and depth of the wells can minimize the geological risk and, thus, may

\footnotetext{
${ }^{*}$ Corresponding author: amwachow@agh.edu.pl
} 
eliminate additional expensive operations. The modeling enables the researchers to forecast the impact of production parameters (discharge, temperature, required discharge and injection pressures) on business plan of the investment and, thus, it rationalizes the possible risk.

The numerical modeling of operation of geothermal waters intake applies mostly the finite differences and/or finite elements methods [9, 10]. The specialized software called "simulator" provides the estimation of the geothermal potential of a given area as well as optimizes the parameters of given installation, which ensures its long lifetime [10-13]. Hence, the initial stage of analysis includes a number of simulations aiming to select e.g., localization of wells, their configuration, diameters and spacing, in order to ensure their optimal future operation [14]. It must be emphasized that numerical models generated during the simulations bear errors, which result from applied simplifications. The numerical modeling processes the available information and yields the quantitative results. However, model based upon incorrect assumptions will provide incorrect results. The significance of generated errors is influenced by correctness of interpretation of available geological, geophysical and other archival data used during the generation of the conceptual model. Moreover, the correctness of obtained results depends on other factors, as e.g. the selection of proper numerical method, the quality of study area discretization, the selection of boundary parameters and the experience of the researcher who performs the modeling [14]. Such experience enables the author of the model to verify the physical correctness of obtained results at the initial stage of calculations.

The modeling described below was carried on with the TOUGH2 simulator, which applies the finite differences method. This software is quite often used in modeling of mass and heat transfer [10]. Modeling was performed for a geothermal doublet composed of production and injection wells. The optimization concerned doublet configuration, including the wells spacing and predicted discharge, in order to ensure long-lasting operation of the whole installation and to prevent the quick thermal drawdown in geothermal reservoir [14].

\section{Conceptual model}

The study area in located in the Central Poland, close to the town of Kalisz. From a geological point of view, the area straddles the boundary between the Łódź Trough and the Fore-sudetic Monocline (Fig. 1), both belonging to the Polish Lowlands. In the Lódź Trough, the most promising resources of geothermal waters are reservoired in the Lower Cretaceous and Lower Jurassic sediments $[15,16]$. The Łódź Trough is commonly described together with the adjacent Mogilno Trough as a joint tectonic unit (Mogilno-Łódź Trough) of axis parallel to that of the Kutno Ridge, but it is narrower and more elongated in relation to the Mogilno Trough [17]. In the Mogilno-Łódź Trough, the thickest Cretaceous succession in Poland was encountered (about 3,000 $\mathrm{m}$ in the vicinity of Turek town). Beneath the Cretaceous formation the Jurassic, Triassic and Permian strata were encountered whereas beneath the Permian-Mesozoic cover the Rotliegend rocks occur [17].

The Łódź Trough is an asymmetric structure of complicated internal setting due to the presence of numerous salt diapirs. It is also regarded as the most depressed fresh water aquifer in Poland, which resulted from intensive exploitation of both the Upper and the Lower Cretaceous aquifers. Consequently, the huge depression cone has formed together with disturbances of hydrogeological regime [17-20].

The Fore-sudetic Monocline is a southwestern limb of the Szczecin-Łódź-Miechów Synclinorium bordered from the southwest by the Odra River Fault and grading to the southeast into the Kraków-Częstochowa Monocline [17]. The monocline is entirely covered by Tertiary and Quaternary sediments. Typical feature is the relatively low thickness of 
both the Permian and the Triassic successions, and pinching out of Permian-Mesozoic formations to the southeast due to tectonic movements at the end of the Jurassic, which resulted in the uplift and erosion of a large part of Permian-Mesosoic, Jurassic and Triassic formations in the southern part of the monocline [17,21].

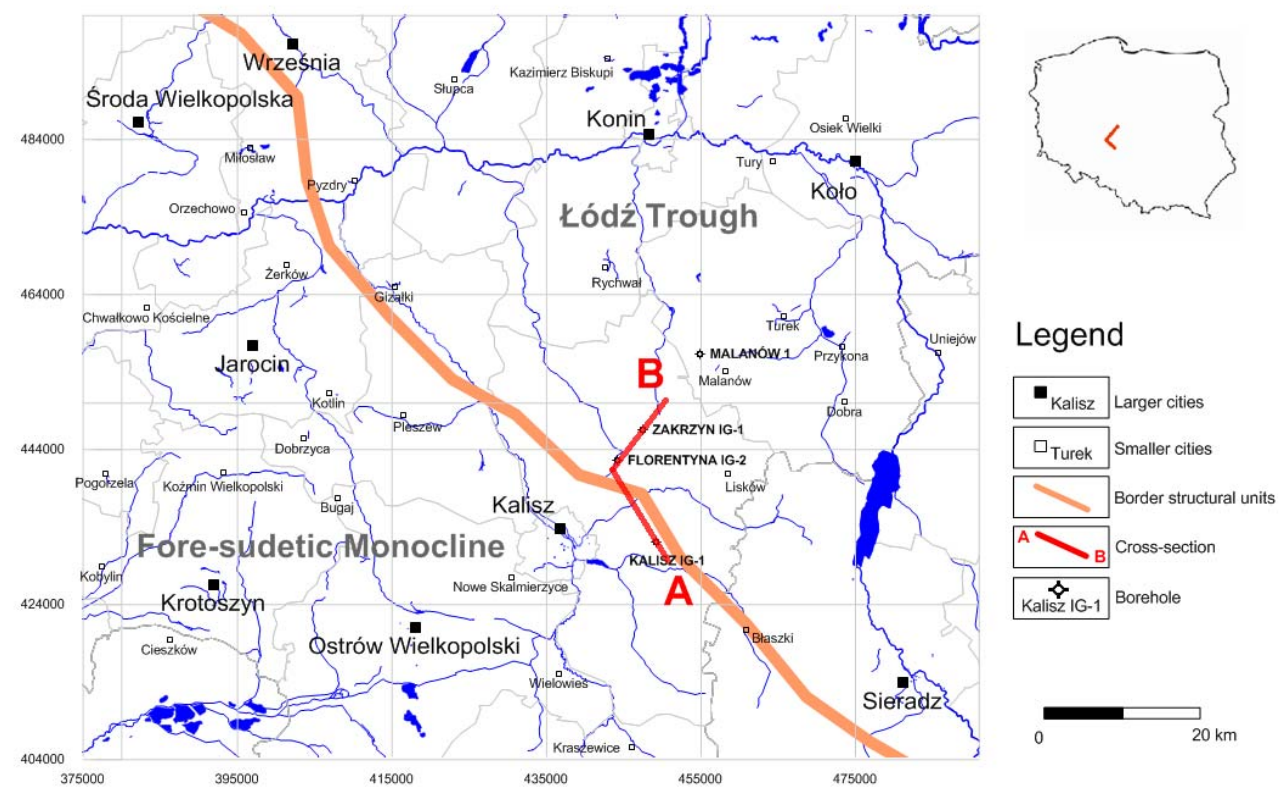

Fig. 1. Location of Zakrzyn IG-1 and Florentyna 1 wells with their geological profiles (based on CBDG data).

In the study area, 4 archival deep wells were located: Kalisz IG-1 (in the Fore-sudetic Monocline), Florentyna IG-2 and Zakrzyn IG-1 (at the boundary of the monocline and the Mogilno-Łódź Trough), and Malanów 1 (in the Mogilno-Łódź Trough).

The analysis of available well profiles reveals distinct plunging of Jurassic sediments to the northeast and pinching out of Cretaceous strata towards the Fore-sudetic Monocline. The Lower Jurassic sediments were drilled in all the analyzed wells but their thickness apparently decreases towards the northeast. The extremal thicknesses of Jurassic strata were encountered in the Kalisz IG-1 well $(>1,200 \mathrm{~m})$ and the minimum thickness was found in the Zakrzyn IG-1 well ( $<1,000$ m) (Fig. 2).

Taking into account the depth to the Lower Jurassic formation and the close neighborhood of Kalisz town, which would ensure potential buyers of thermal energy, the Zakrzyn IG-1 well was selected as the production well for a designed geothermal doublet.

The main objective of the Zakrzyn IG-1 well was to enhance the recognition of the uplifted part of Permian basement in the vicinity of Kalisz, particularly the setting of subPermian basement structures, the litho facial development of penetrated structures, the thickness of Rotliegend formations and the reservoir properties of Carboniferous complex [22]. 


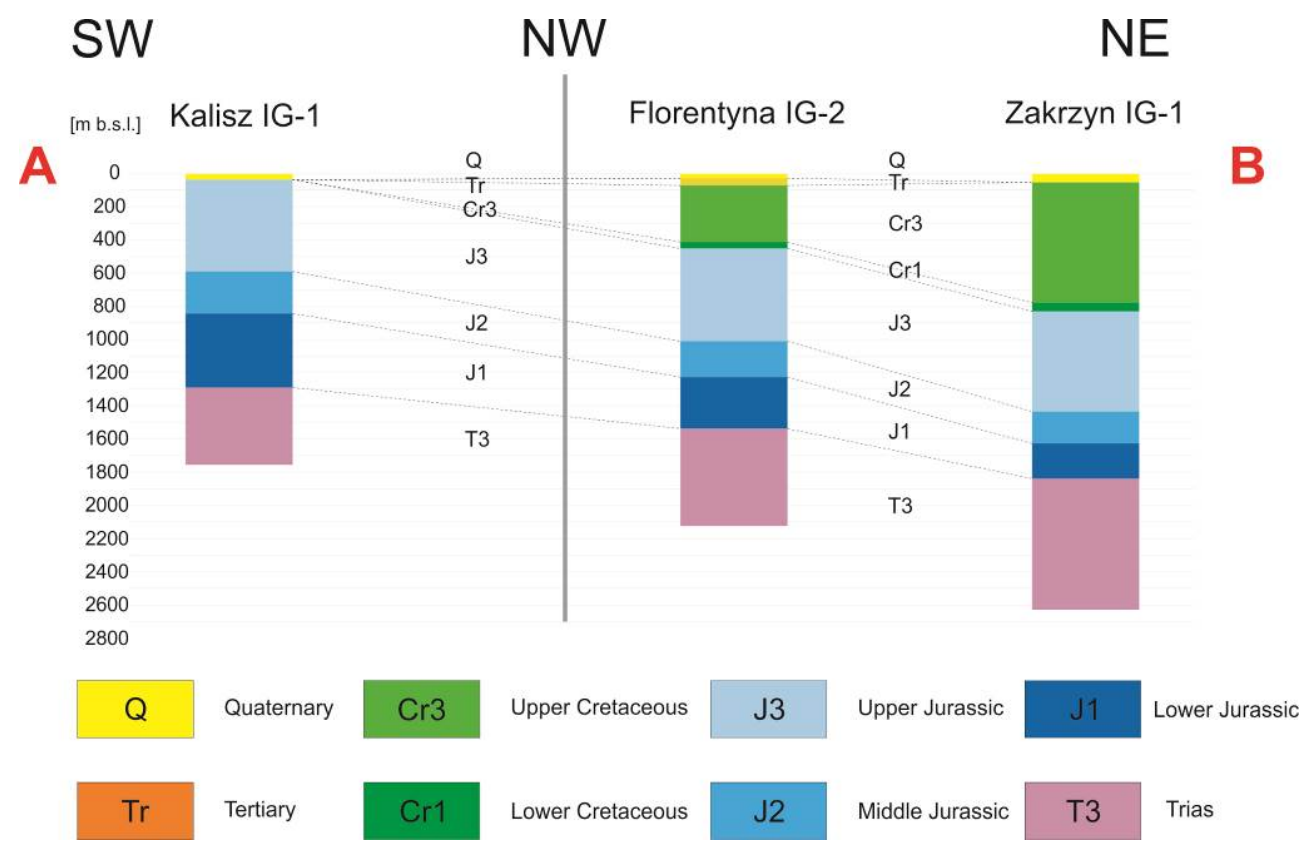

Fig. 2. Stratigraphic columns of deep wells (based on CBDG data) along the cross-section from Fig. 1.

The heat flux in the Polish Lowlands, in the vicinity of Kalisz, varies from 70 to $100 \mathrm{~mW} / \mathrm{m}^{2}$ [23]. These values undoubtedly influence the temperatures of groundwaters, which rise from 30 to over $90^{\circ} \mathrm{C}$ towards the northeast [15]. This temperature range was confirmed by the results of measurements carried on in deep wells during and after the drilling operations. For example, in the Zakrzyn IG-1 well, the temperature of deep waters in the Rotliegend aquifer was $143^{\circ} \mathrm{C}$ at $4,329 \mathrm{~m}$ depth b.s.l. The analysis of well data proved that the best geothermal reservoir is the Liassic formation encountered in the Zakrzyn IG-1 well, which effective porosity is about $16 \%$ [22]. The potential extraction/reinjection flow rate of geothermal doublets in the vicinity of Kalisz is about $150 \mathrm{~m}^{3} / \mathrm{h}$ and increases to the northwest to $300 \mathrm{~m}^{3} / \mathrm{h} \mathrm{[15]}$.

\section{Numerical model}

The numerical model developed from the conceptual model covers an area of about 100 $\mathrm{km}^{2}$ (Fig. 3). The geothermal doublet is based upon the archival Zakrzyn IG-1 well, which was designed as production well.

Considering the geological data, the model was divided into 6 stratigraphic subdivisions, which included:

1. Cenozoic, Cretaceous and Jurassic sediments down to $825 \mathrm{~m}$ depth b.s.l., thickness: $825 \mathrm{~m}$,

2. Middle Jurassic sediments down to 1,624.5 m depth b.s.1., thickness: $799.5 \mathrm{~m}$,

3. Lower Jurassic (Toarcian) sediments down to 1,692.0 m b.s.1., thickness: $67.5 \mathrm{~m}$,

4. Lower Jurassic (Pliensbachian) sediments down to 1,790.0 m depth b.s.l., thickness: $98 \mathrm{~m}$,

5. Lower Jurassic (Sinemurian) sediments down to 1,824.5 m depth b.s.l., thickness: $34.5 \mathrm{~m}$,

6. Triassic sediments down to $2,600 \mathrm{~m}$ depth b.s.l. 


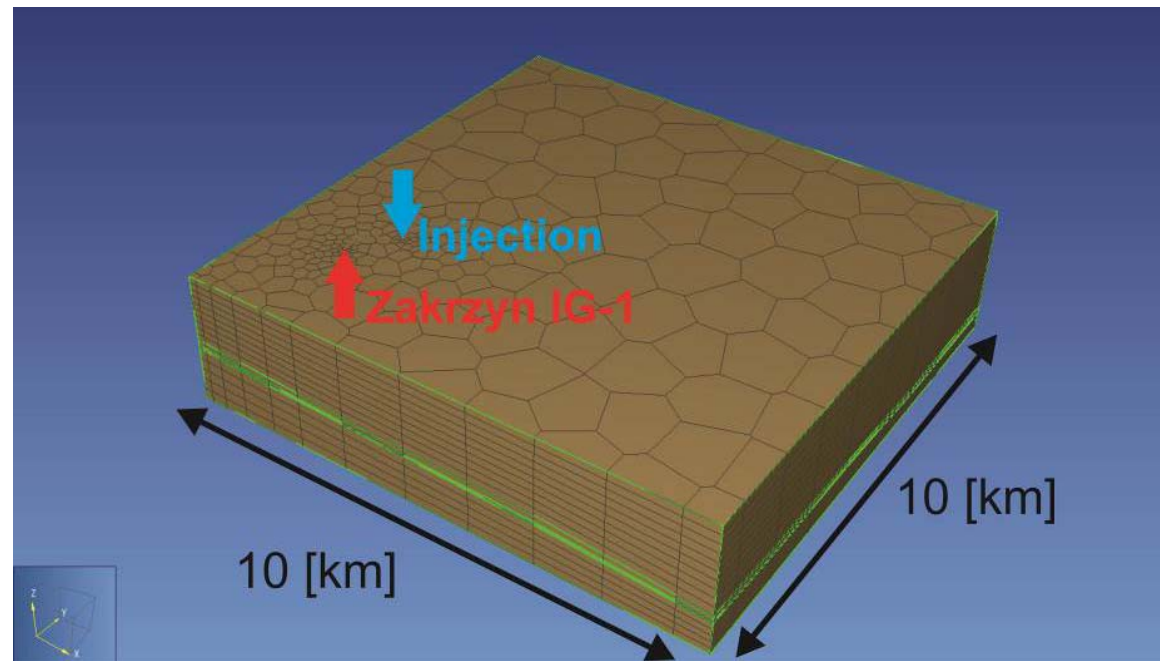

Fig. 3. Scheme of space discretization used in the numerical model. Production and injection wells are indicated.

Basing on the conceptual model, the following reservoir parameters were ascribed to each stratigraphic subdivision: density $\left[\mathrm{kg} / \mathrm{m}^{3}\right]$, effective porosity $[\%]$ and permeability $[\mathrm{mD}]$ (in three directions XYZ) as well as heat transfer coefficient $\left[\mathrm{W} /\left(\mathrm{m}^{*} \mathrm{~K}\right)\right]$ and specific heat $[\mathrm{J} /(\mathrm{kg} * \mathrm{~K})]$ (see Tab. 1).

Table 1. Defined parameters of model for Kalisz area.

\begin{tabular}{|c|l|l|c|c|c|c|}
\hline No. & $\begin{array}{c}\text { Stratigraphic } \\
\text { subdivision }\end{array}$ & $\begin{array}{c}\text { Density } \\
{\left[\mathbf{k g} / \mathbf{m}^{3}\right]}\end{array}$ & $\begin{array}{c}\text { Porosity } \\
{[\%]}\end{array}$ & $\begin{array}{c}\text { Permeability } \\
{[\mathbf{m D}]} \\
\text { in directions } \\
\mathbf{X} ; \mathbf{Y} ; \mathbf{Z}\end{array}$ & $\begin{array}{c}\text { Heat } \\
\text { transfer } \\
\text { coefficient } \\
{[\mathbf{W} /(\mathbf{m} * \mathbf{K})]}\end{array}$ & $\begin{array}{c}\text { Specific } \\
\text { heat } \\
{[\mathbf{J} /} \\
(\mathbf{k g * K})]\end{array}$ \\
\hline 1 & $\begin{array}{l}\text { Cenozoic }+ \\
\text { Cretaceous }\end{array}$ & $2,600.0$ & 1.0 & $50 ; 50 ; 5$ & 2.0 & 1,000 \\
\hline 2 & Middle Jurassic & $2,600.0$ & 2.0 & $0.01 ; 0.01 ; 0.001$ & 2.0 & 1,000 \\
\hline 3 & Toarcian & $2,600.0$ & 7.0 & $50 ; 50 ; 5$ & 3.5 & 1,000 \\
\hline 4 & Pliensbachian & $2,600.0$ & 12 & $250 ; 250 ; 25$ & 3.5 & 1,000 \\
\hline 5 & Sinemurian & $2,600.0$ & 12 & $250 ; 250 ; 25$ & 3.5 & 1,000 \\
\hline 6 & Triassic & $2,600.0$ & 0.1 & $0.01 ; 0.01 ; 0.001$ & 3.5 & 1,000 \\
\hline
\end{tabular}

In the next modeling step, a rectangular mesh was superimposed on the model. For the bottom and the top stratigraphic subdivisions, the Dirichlet boundary condition was applied by ascribing constant pressure and temperature values. Then, the model was calibrated using the temperature log of the Zakrzyn IG-1 well in order to correct the boundary conditions (temperature and pressure values). In the next step, the production and the injection wells were introduced into the model, and the polygonal mesh was superimposed. The change of mesh type enabled the densification of mesh nodes in the vicinity of the wells, which improved the modeling accuracy at these sites. Then, the model was again calibrated.

It was assumed that the production well will exploit the geothermal water horizon within the Lower Jurassic (Pliensbachian) formation at 1,700 $\mathrm{m}$ depth b.s.l. The injection 
well was also designed to penetrate the Liassic formation, which enabled the closure of geothermal water circulation system within the Lower Jurassic aquifer. The numerical model was verified by comparison of calculated and measured values of reservoir parameters. The modeling results were evaluated as satisfactory (Fig. 4).

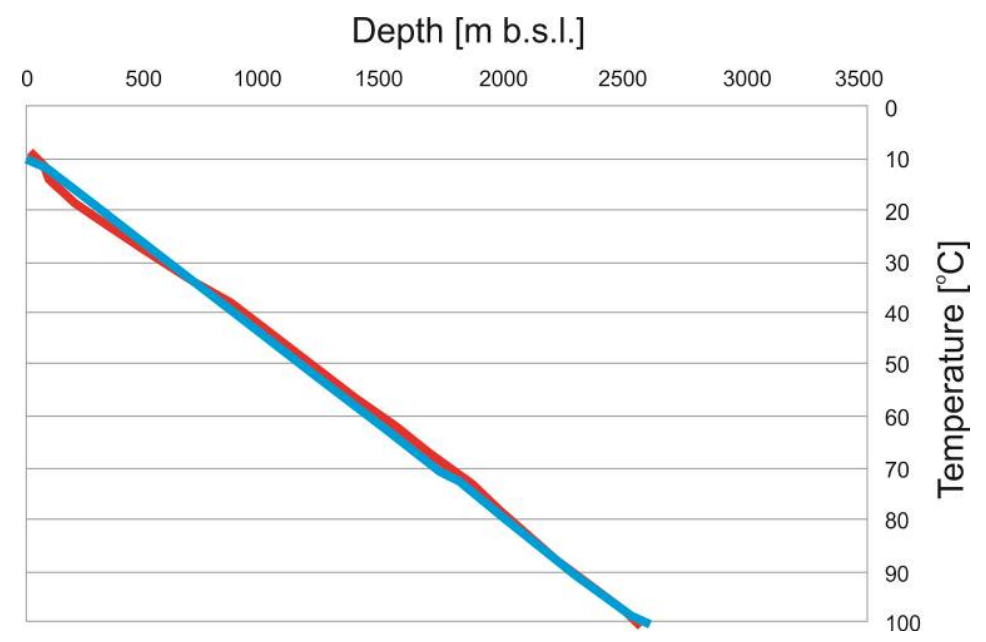

Fig. 4. Results of numerical model calibration (red - measured values, blue - modeled values).

\section{Selection of doublet wells spacing}

In the first modeling step, the spacing of production and injection wells was analyzed in order to optimize the operation of geothermal doublet. The too-close spacing of both wells may cause cooling of the reservoir too quickly and an excessive temperature drop, which would result in thermal power drawdown of the whole geothermal system. On the contrary, the too-distant wells force the excessive length of connecting installations, which raises production costs of the system.

The modeling was carried out for four consecutive spacing variants: $500 \mathrm{~m}, 1,000 \mathrm{~m}$, 2,000 $\mathrm{m}$ and 3,000 $\mathrm{m}$ (Fig. 5).
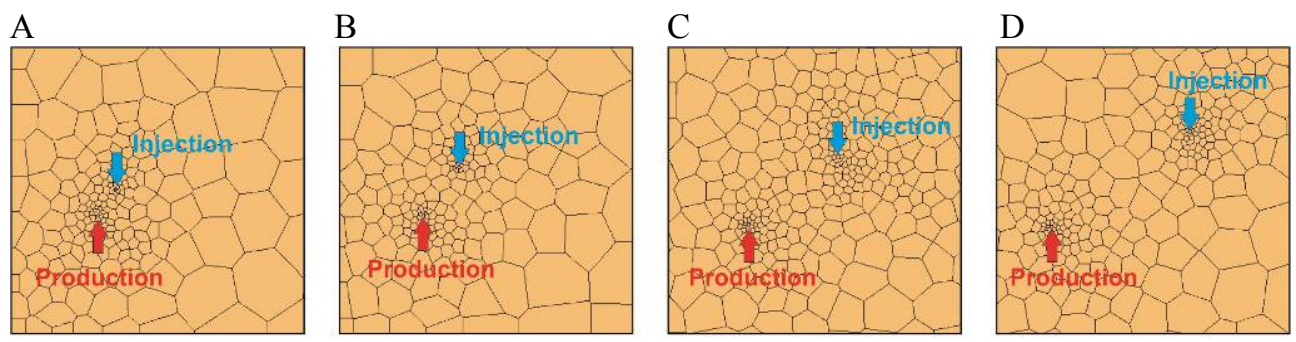

Fig. 5. Spacing variants of production and injection wells: A- $500 \mathrm{~m}, \mathrm{~B}-1,000 \mathrm{~m}, \mathrm{C}-2,000 \mathrm{~m}, \mathrm{D}-$ $3,000 \mathrm{~m}$.

For each spacing variant, the same boundary parameters were assumed: water discharge $120 \mathrm{~m}^{3} / \mathrm{h}$, injected water temperature $25^{\circ} \mathrm{C}$ and a 50 -year-long lifetime of the installation, as well as the same density of calculation mesh. The calculation step was automatically selected by the TOUGH2 software. For each step, pressure and temperature values were analyzed in both the production and injection wells (Fig. 6). 

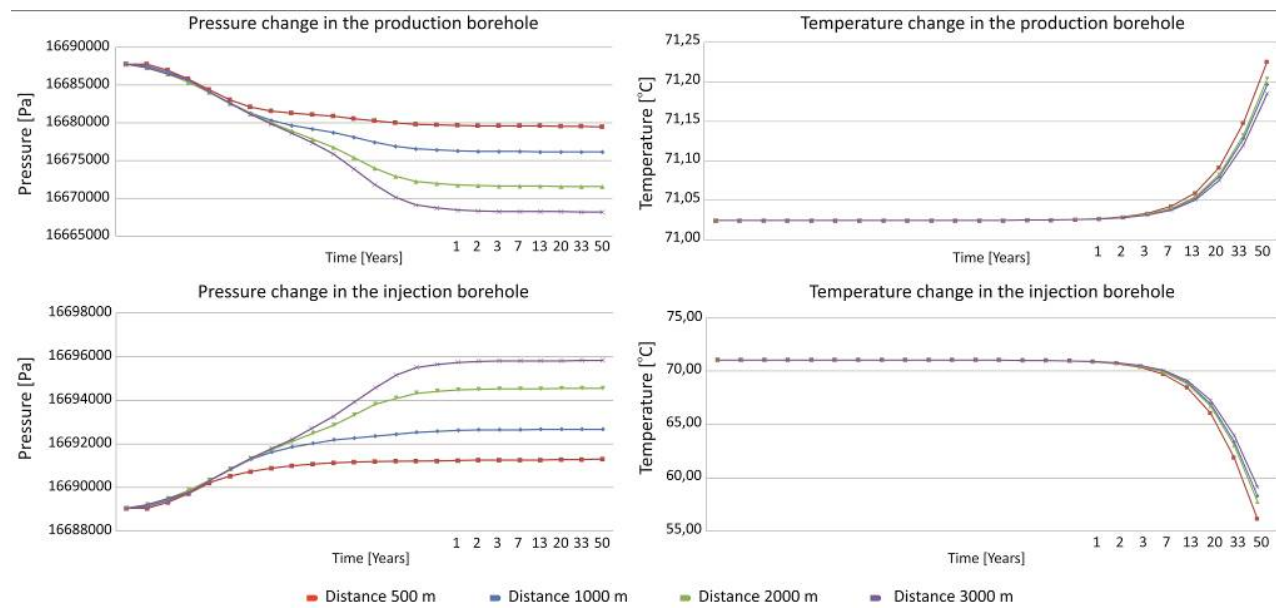

Fig. 6. Pressure and temperature changes in geothermal doublet dependent on spacing of production and injection wells.

In the production well, the modeling revealed a distinct pressure drop before the end of the first exploitation year, followed by pressure stabilization. The value of pressure drop was directly proportional to the increasing spacing between the wells. Similarly, in the injection well, general pressure increase was observed together with distinct pressure fluctuations. Then, the pressure had stabilized, as in the production well.

A slight increase of temperature (about $0.3^{\circ} \mathrm{C}$ ) was observed in the production well after about 2 years of exploitation, presumably related to some inflow of water from deeper and warmer parts of the reservoir. Temperature differences were moderate except for higher values noticed for $500 \mathrm{~m}$ spacing. The temperature drop was noticed, as well, but not below $55^{\circ} \mathrm{C}$ and it did not affect the temperature in the production well (Fig. 7).
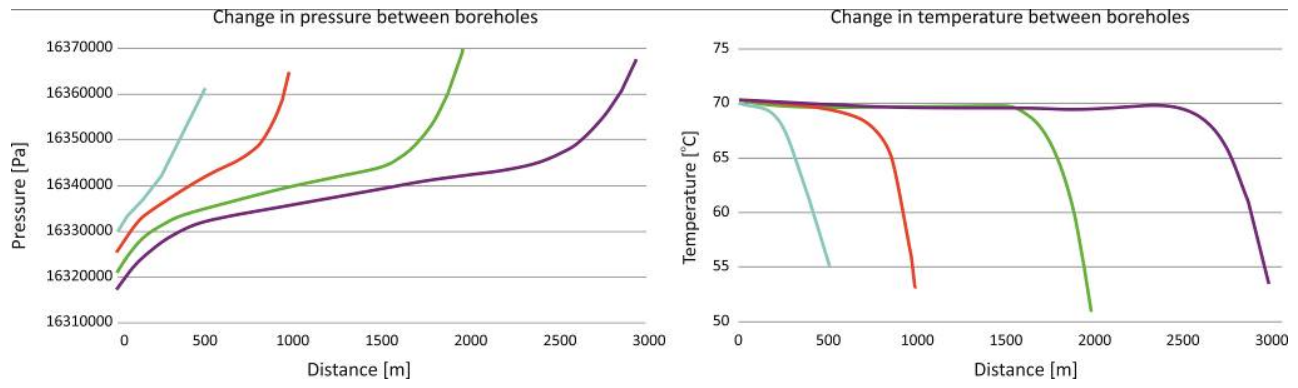

Fig. 7. Changes of pressure and temperature at depth $1,700 \mathrm{~m}$ b.s.l. (blue - distance $500 \mathrm{~m}$, red - distance $1,000 \mathrm{~m}$, green - distance $2,000 \mathrm{~m}$, purple - distance 3,000 m ).

\section{Selection of production discharge}

The second, equally important parameter controlling the thermal power of geothermal water intake is the water discharge. The excessive fluid flow may result in cooling of the reservoir in the vicinity of the production well and may generate problems with wellhead pressures. On the contrary, too small of a discharge would lower the thermal power of the system, which may become unable to cover the demand for energy.

A number of numerical modelings analyzed various discharge values: 120, 150, 180, 210, 240,270 and $300 \mathrm{~m}^{3} / \mathrm{h}$. For each discharge value, distributions of temperature and pressure were modeled in both the production and the injection wells, similarly to well spacing modeling. 
The production well revealed pressure stabilization after almost a year of exploitation whereas the injection well showed pressure fluctuations at the initial stage of exploitation followed by stabilization at the end of first year of exploitation (similarly to the production well). Such behavior of pressure is similar to those obtained in modeling of well spacing.

In the vicinity of the production well, a slight increase of reservoir temperature was observed after 2 years of exploitation: from 71.05 to $71.35^{\circ} \mathrm{C}$, proportionally to the increasing discharge. In the injection well, similar changes of reservoir temperatures were observed after 2 years of exploitation. However, in all analyzed discharge variants, the reservoir temperatures did not drop below $45^{\circ} \mathrm{C}$. The results of pressure and temperature modeling at presumed $1,000 \mathrm{~m}$ wells spacing are presented in Fig. 8.
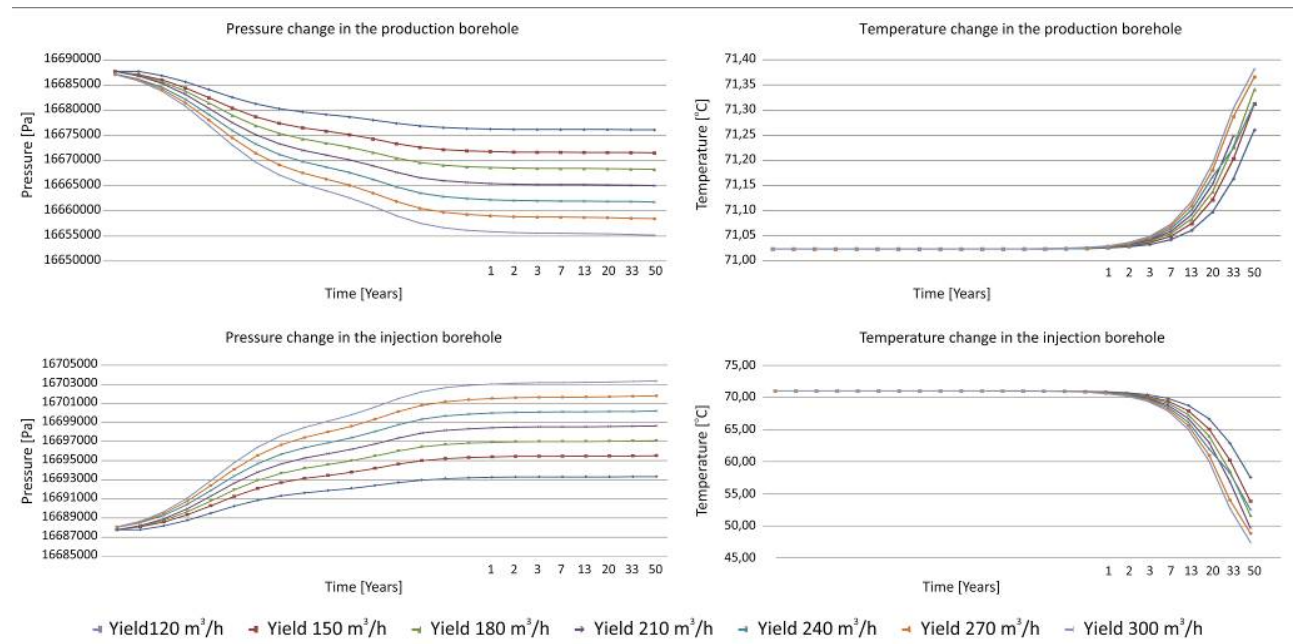

Fig. 8. Pressure and temperature changes in geothermal doublet at various discharge values and at $1,000 \mathrm{~m}$ spacing of production and injection wells.

\section{Summary}

The modeling of optimal configuration and discharge of geothermal doublet was carried on for potential geothermal installation to be designed in the vicinity of Kalisz. The existing Zakrzyn IG-1 well located close to the town was selected as a production well. It must be emphasized that economic effectiveness of the reconstruction of the Zakrzyn IG-1 well has not been analyzed. Such operation can be very expensive but the authors considered the fact that the archival wells have already been successfully developed in geothermal installations operating in Mszczonów and in Uniejów.

First, the spacing between the production and injection wells was modeled using several spacing variants, from 500 to $3,000 \mathrm{~m}$. Analysis of pressures and temperatures in both wells led to the selection of $1,000 \mathrm{~m}$ spacing as optimal for future geothermal installation.

The second modeling step concerned the influence of various discharge values on changes of production parameters. For each configuration of wells, pressure changes were analyzed (increasing around the production well and decreasing around the injection well). The modeling showed that these pressure changes are proportional to discharge variations. In the production well, no significant temperature drops were observed for various discharge values. Hence, the safe operation of future doublet is expected within the scheduled production lifetime as the cold water breakthrough into the production well has not occurred in the model. 
It must be emphasized that our modeling revealed lower vulnerability of the doublet to spacing between the wells than to discharge of production well. The results allow us to consider all modeled variants as safe for operation of designed geothermal installation during its assumed 50-year-long lifetime. A small temperature increase in the production well and a decrease in the injection one, which appeared in all variants after the first year of exploitation did not affect the operation of designed installation.

Taking into account the close proximity of Kalisz, which is expected to provide the main thermal energy buyers, utilization of geothermal waters from the Lower Jurassic aquifer seems to be a good alternative for combustion of fossil fuels. The geothermal installation will contribute to reduction of air pollution in the town and will improve the utilization level of alternative energy sources in Poland.

The research was financed by the AGH UST grants No. 11.11.140.031 and 11.11.150.008.

\section{References}

1. M. Miecznik, A. Sowiżdżał, B. Tomaszewska, L. Pająk, Modelling geothermal conditions in part of the Szczecin Trough - the Chociwel area. Geologos 21, 3, 187-196 (2015)

2. W. Bujakowski, A. Barbacki, M. Miecznik, L. Pajak, R. Skrzypczak, A. Sowizdzał, Modelling geothermal and operating parameters of EGS installations in the lower triassic sedimentary formations of the central Poland area. RENEW ENERG 80, 441453 (2015)

3. M. Miecznik, Problematyka modelowania numerycznego 3D złóż geotermalnych, Technika Poszukiwań Geologicznych. Geotermia Zrównoważony Rozwój No. 1-2/2010, 61-73 (2010)

4. J. Chowaniec, Studium hydrogeologii zachodniej części Karpat polskich. Biuletyn Państwowego Instytutu Geologicznego, 58, 762-773 (2009)

5. A. Sowiżdżał, Perspektywy wykorzystania zasobów wód termalnych jury dolnej z regionu niecki szczecińskiej (północno-zachodnia Polska) w ciepłownictwie, balneologii i rekreacji. Przegląd Geologiczny, 58, 613-621 (2010)

6. A. Sowiżdżał, Perspektywy wykorzystania zasobów geotermalnych jury dolnej w północno-zachodniej części Polski do celów ciepłowniczych, balneologicznych i rekreacyjnych. Przegląd Geologiczny, 57/8, 660-661 (2009)

7. A. Sowiżdżał, B. Papiernik, G. Machowski, M. Hajto, Characterization of petrophysical parameters of the Lower Triassic deposits in prospective location for Enhanced Geothermal System (central Poland). Geological Quarterly, 57, 729-744 (2013)

8. A. Sowiżdżał, B. Papiernik, G. Machowski, Rola modelowania strukturalnoparametrycznego $\mathrm{w}$ procesie typowania potencjalnej lokalizacji zamkniętych systemów geotermicznych w skałach osadowych. Przegląd Geologiczny, 62/6, 303-307 (2015)

9. S. Dąbrowski, J. Kapuściński, K. Nowicki, J. Przybyłek, A. Szczepański,(Metodyka Modelowania Matematycznego W Badaniach I Obliczeniach. Hydro-geologicznych Poradnik, 306 (2010)

10. M. Dendys, B. Tomaszewska, L. Pająk, Modelowanie numeryczne jako narzędzie wspomagające badania systemów geotermalnych, [W:] A. Krawc, I. Jamorowska, (Modelowanie w Hydrogeologii, Wyd. Naukowe Uniwersytetu Mikołaja Kopernika, 199-206 2014) 
11. M. Dendys, B. Tomaszewska, L. Pająk, Numerical modelling in research on geothermal systems. Bulletin of Geography. Physical Geography Series, 9, 39-44 (2015)

12. R. Zdechlik, B. Tomaszewska, M. Dendys, L. Pająk, Przegląd oprogramowania do numerycznego modelowania procesów środowiskowych w systemach geotermalnych. Przegląd Geologiczny No. 10/2, 63,1150-1154 (2015)

13. A. Sowiżdżał, Zastosowanie technik cyfrowej kartografii wgłębnej do rozpoznania potencjału geotermalnego zapadliska Przedkarpackiego - Przegląd Geologiczny; 62/12, $842-845$ (2014)

14. A. Wachwoicz-Pyzik, A. Sowiżdżał, L. Pająk, Wykorzystanie modelowania numerycznego do określenia wpływu konfiguracji otworów na parametry eksploatacyjne dla dubletu geotermalnego w rejonie Choszczna. Czasopismo Inżynierii Lądowej, Środowiska i Architektury, T. 33, Z. 63 No. 4, 553-564 (2016)

15. W. Górecki et. al., Atlas zasobów geotermalnych na Niżu Polskim, ZSE, AGH, Towarzystwo Geosynoptyków Geos, Kraków, 484 (2006)

16. W. Górecki, A. Sowiżdżał, M. Hajto, A. Wachowicz-Pyzik, Atlases of geothermal waters and energy resources in Poland. Environmental Earth Sciences, 74, I. 12, 74877495 (2015)

17. E. Stupnicka, Geologia regionalna Polski. Wydawnictwa Uniwersytetu Warszawskiego, 205 (1997)

18. B. Paczyński (red.), Atlas hydrogeologicznej Polski. Państw. Inst. Geologiczny, Warszawa (1995)

19. Bojarski (red.), Atlas hydrochemiczny i hydrodynamiczny paleozoiku i mezozoiku oraz ascensyjnego zasolenia wód podziemnych na Niżu Polskim. Wyd. PIG, Warszawa (1996)

20. B. Wiktorowicz, Możliwości wód termalnych w niecce łódzkiej. Technika Poszukiwań Geologicznych Geotermia, Zrównoważony Rozwój, 1 /2, 329-337 (2011)

21. J. Sokołowski, Obszar przedsudecki W: Budowa geologiczna Polski T. IV, P. 1. Wyd. Geol. Warszawa , 101 (1974)

22. Z. Deczkowski, Dokumentacja wynikowa otworu badawczego: ZAKRZYN IG-1, SW/SZ/505, PGNiG S.A., Warszawa; 129223, CAG, PIG, Warszawa (1984)

23. J. Szewczyk, M. Hajto, Strumień cieplny a temperatury wgłębne na obszarze Niżu Polskiego. Heat flow versus sub-surface temperatures in the Polish Lowlands, [W:] W. Górecki (red.), 2006 - Atlas zasobów geotermalnych na Niżu Polskim. Formacje mezozoiku, MŚ, NFOŚiGW, AGH, PIG, Kraków,143-148, 149-151 (2006) 